\title{
NOTES
}

DR. F. P. Bowden of the Physical Chemical Department, Cambridge University, has been elected to fellowship of the Royal Society. Dr. Bowden is an experienced mountaineer and ski-er and assisted in the organization of the Jungfraujoch Glaciological Research Party, 1937-38.

Professor F. Debenham has been awarded the Victoria Medal of the Royal Geographical Society for his work in geographical education and his contributions to polar geography, to Antarctic exploration and as first Director of the Scott Polar Research Institute, Cambridge.

Mr. GoRdon Manley has been appointed to the newly inaugurated chair of geography at Bedford College, University of London.

"The Arctic Circle." A club with this appropriate name has been formed in Ottawa for those interested in Arctic exploration and research. The prime movers in this new venture are Mr. T. H. Manning and Lieut.-Col. and Mrs. G. W. Rowley, all members of the British Glaciological Society. Mr. Manning has recently received the Patron's Medal of the Royal Geographical Society for his explorations and survey work in the Canadian Arctic.

Articl.es in Foreign Languages. The publication of articles in foreign languages in the Fournal of Glaciology has been under consideration. Discussion with members and subscribers in Switzerland showed that about half were in favour of this, while the others thought it barely necessary. It is felt that for the present brief abstracts of certain articles in foreign languages should suffice.

Archiv für Meteorologie, Geophysik und Bioklimatologie. This new journal has been published in order to fill the gap caused by the disappearance of many scientific publications, particularly those in Germany, during the war years. It is to appear at irregular intervals and will be in two parts-Series A dealing with meteorology and geophysics, Series B with general biological climatology. Each series can be subscribed for separately. The editors are Professor Dr. F. Steinhauser, Zentralanstalt für Meteorologie und Geodynamik, Vienna, and Dr. W. Mörikofer, Physikalisch-Meteorologisches Observatorium, Davos, Switzerland. The publishers are the Springer-Verlag, Mölkerbastei 5 , Vienna $\mathbf{I}$. The journal will include the climatological and physiological aspects of snow cover but probably not the study of glaciers and other glaciological subjects.

The Glacialists Magazine. Dr. J. N. Carruthers has sent some details of this journal, which flourished for a short time at the end of last century. It appeared in 1893 under the editorship of P. F. Kendal and was published monthly. Later issues came out quarterly and it seems to have ceased publication at the end of 1897 . It contained much of interest to the glacial geologist and it is to be regretted that its life was not longer.

\section{FIRST INTERNATIONAL COURSE FOR THE STUDY OF SNOW AND AVALANCHES}

AN instructional course was organized in December 1947 at the Swiss Snow and Avalanche Research Station at the Weissfluhjoch, Davos.* The instruction consisted of lectures and demonstrations dealing with physics, crystallography and meteorology as applied to snow and ice. The plastic properties and temperatures of the snow cover received special attention. Practical work in the field included the digging of snow sections and the sounding of deep snow accumulations. The dislodging of avalanches by mine-throwers and grenades was demonstrated, and rescue work

* Eidgenossisches Institut für Schnee- und Lawinenforschung. 